\title{
FEATURES OF THE ASSESSMENT OF FACTORS INFLUENCING PRODUCTIVITY
}

\author{
Irena DANILEVIČIENE்(iD ${ }^{1,2 *}$ \\ ${ }^{1}$ Department of Financial Engineering, Faculty of Business Management, \\ Vilnius Gediminas Technical University, Saulètekio al. 11, LT-10223, Vilnius, Lithuania \\ ${ }^{2}$ Labour Market Research Institute, Lithuanian Social Research Centre, \\ Goštauto g. 11, LT-01108, Vilnius, Lithuania \\ ${ }^{*}$ E-mail: irena.danileviciene@vgtu.lt
}

\begin{abstract}
Purpose - productivity is an economic category that is dependent on many internal and external factors and the assessment and management of these factors positively affects the country's economic situation. The aim of this article is to identify the main factors that influence productivity and their relationship.
\end{abstract}

Research methodology - the methodology of the article give information about the Granger causality test that was applied in order to assess the factors influence on productivity.

Findings - the results of deeper researches of productivity and the assessment of the selected factors have shown that the strongest impact on productivity has the investments and wages.

Research limitations - at this article the following research limitations are applied: amount (due to the analysis of productivity and its determinants it is possible to mention that not all factors that have an influence on productivity are included in the concept of research), time (the data of the 1995-2017 y.y. are analyzed) and the method (the most appropriate alternative for the analysis is the use of the Granger causality test).

Practical implications - the improvement of the country's economic situation is possible due to the targeted management of the factors, that have the greatest impact on productivity.

Originality/Value - new variables are included in the analysis of productivity and factors that have an influence on it and the evaluation of these factors is carried out in the case of Baltic States.

Keywords: capital, employment, Granger causality test, investment, productivity, wage.

JEL Classification: D24, E24, J24, O47.

Conference topic: Contemporary Financial Management.

\section{Introduction}

Productivity is an economic category that depends on many internal and external factors. Purposeful assessment and management of these factors positively affect the country's economic situation. The expected higher return, targeted use of available resources and foreign investment motivate the growth of productivity and consequently the improvement of the country's economic situation. In order to increase productivity, there is a need to increase the wages as a purchasing power rate, so the opportunities to increase the productivity level are searching due to the properly analyse of the current situation and modelling the solutions of practical problems.

Due to the fact, that productivity is an economic category that is dependent on many internal and external factors and the assessment and management of these factors positively affects the country's economic situation, the main objective of this article - to identify the main factors that influence productivity. Trying to assess the factors influence on productivity the most suitable method is the Granger causality test.

The Granger causality test is applied to implement few research limitations. At this article, it is possible that not all factors that have an influence on productivity are included in the concept of the 1995-2017 y. y. data analysis using the Granger causality test. It is necessary to notice that all the improvement of the country's economic situation is possible due to the targeted management of the wage, employment, investment and capital, that have the greatest impact on productivity.

The results of deeper researches of productivity and the assessment of the selected factors have shown that in the context of Latvia, Lithuania and Estonia the strongest impact on productivity has the investments and wages. Also, 
new variables like investment and capital are included in the analysis of productivity and the assessment of wage and employment factors is carried out in the case of Latvia, Lithuania and Estonia.

This article consists of these parts: introduction, theoretical analysis of productivity and factors that have an influence on it (like the wage, employment, investment and capital), practical analysis aspects of the benefits of a cointegration test and Granger causality test calculation for the assessment of productivity and its determinants, conclusions.

\section{Theoretical peculiarities of productivity}

Productivity category is one of the key categories of economic science. Based on the economic science thesis, productivity includes the efficiency of the use of production factors and specifies the rationality of management conditions and justification of the effects at the micro and macro level (Grześ, 2017).

Generally, productivity is understood as the ratio between the obtained outputs and produced inputs or the rate between produced and sold products with the resources used (Grześ, 2017). Due to the efficient use of the available resources the higher productivity is reached. The changes in productivity may lead to a composition of employment, can influence the measurement of employee's contributions and accordingly have an impact on the determination of wage size (Peluffo, 2015). As a result, the proper use of human resources is an essential prerequisite for economic development and increasing productivity means the better methods of management is used in the activity and employees have gained useful knowledge.

On the other hand, productivity is defined as ,the ability to create the added value by using the available production factors", so to make the targeted use of labour and capital resources. In this context detailing the concept of productivity, it turned out that productivity is an important measure that "enables us to identify invisible trends in markets and decision-making process" (Baležentis, 2013). The assessment of economic competitiveness is determined through the important aspects, in particular by evaluating strategic decisions of economic development according to common criteria. Measurement involves the evaluation of different sources of economic competitiveness, but it should also take into account the key factors of labour productivity (Figure 1).

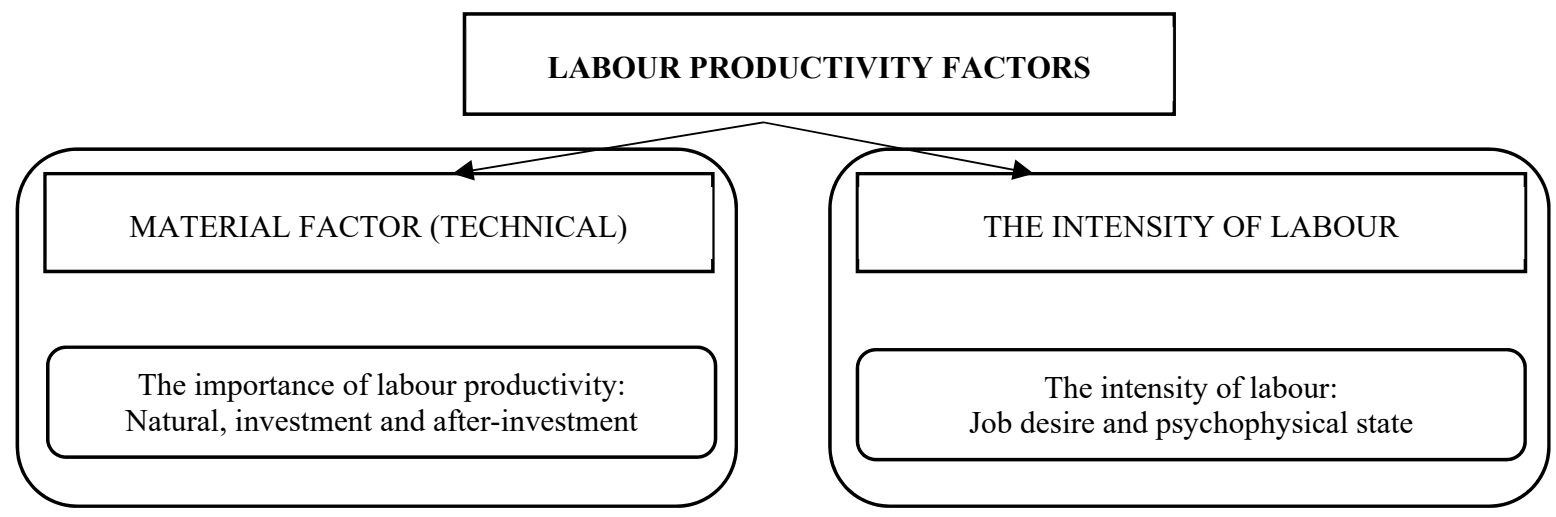

Figure 1. Factors of labour productivity (source: compiled by the author based on Sawicki, 2015)

Sawicki (2015) provides the distribution of labour productivity factors to the importance of labour productivity and the intensity of labour. Accordingly, these factors are defined as material (natural, investment and after-investment) and human (job desire, psychophysical state). The set of these labour productivity factors provides preconditions for economic development.

Summary, productivity is the actual expression of the efficiency of use of the production factors, which specifies the rationality of the management decisions making and base the expediency of the received effects. The factor of labour productivity is characterized by the need for the development of technological and human resources. If the employees were motivated to work properly, they are adapting to constantly changing environmental conditions, through market monitoring and flexible forms of employment, productivity will increase and, accordingly, the competitiveness position of a particular country due to the other countries will be improved.

\section{The system of factors influencing productivity}

The influence of the country's political, economic, social and technological environment on economic progress has recently been widely analyzed. The idea is that social, historical, cultural, institutional and political factors and the administrative context have a decisive influence on the development process in the perspective of national and regional growth and productivity of companies. Productivity is characterized by several aspects: productivity growth factors, productivity-enhancing processes at the national level and technology deployment. "Technologies, its development 
and benefits $<\ldots>$ have an impact on employment and wages" (Annunziata \& Bourgeois, 2018). "Innovations and technologies affect employment through the labour market flexibility, market competitiveness, types of innovations, innovation system and international trade" (Ugur, Churchill, \& Solomon, 2018). It means, that investment to the application of new technologies and upgrading of people's skills pay off when the forms of employment become more flexible, wage rise and productivity increase. Growing productivity improves competitiveness and key macroeconomic indicators (Flachenecker, 2018). However, if "productivity increase, labour costs are reduced and it promotes the export and the creation of value added" (Ottaviano, Peri, \& Wright, 2018) and there is a need for an analysis of the link between productivity and its factors. This section provides more information about productivity and identifies the key factors that determine it.

\subsection{Factors determining productivity}

The integration of labour productivity, employment / unemployment and wage is an important economic and legal issue that is closely related to competitiveness in macro level. Higher capital increases labour demand and wage and thus promotes the growth of productivity. In macroeconomic perspective globalization and the countries openness to internal trading, the growth of productivity and wage becomes a key factors of countries international competitiveness. The growth of productivity promotes economic development (Karaalp-Orhan, 2017), so the most common object of scientific researches is the link between productivity, wage and other factors (Table 1).

Table 1. The relation between productivity, wage, employment and other factors (source: compiled by the author based on scientific literature analysis)

\begin{tabular}{|c|c|c|c|}
\hline Results & Countries & Period & Sources \\
\hline $\begin{array}{l}\text { The positive relation between productivity, } \\
\text { wage and unemployment }\end{array}$ & $\begin{array}{l}\text { Turkey, United King- } \\
\text { dom }\end{array}$ & $\begin{array}{l}1955-1991 \\
2007-2016\end{array}$ & \multirow{4}{*}{$\begin{array}{l}\text { Strauss \& Wohar, 2004; } \\
\text { Yusof, 2008; } \\
\text { Trpeski \& Tashevska, } \\
\text { 2009; } \\
\text { Karaalp-Orhan, } 2017 .\end{array}$} \\
\hline $\begin{array}{l}\text { The negative relation between wage and em- } \\
\text { ployment }\end{array}$ & Malaysian industry & $1992-2005$ & \\
\hline $\begin{array}{l}\text { The relation between price level, wage and } \\
\text { productivity over a long period of time }\end{array}$ & USA (at branch level) & $1956-1996$ & \\
\hline $\begin{array}{l}\text { The relation between wage, labour costs and } \\
\text { productivity }\end{array}$ & $\begin{array}{l}\text { EU, The Republic of } \\
\text { Macedonia, Slovenia }\end{array}$ & $\begin{array}{l}1960-2001 \\
1995-2007\end{array}$ & \\
\hline
\end{tabular}

The results of scientists (Strauss \& Wohar, 2004; Yusof, 2008; Trpeski \& Tashevska, 2009; Karaalp-Orhan, 2017) research shows that there is a relation between productivity, wage, employment/unemployment, prices level and labour costs. Wage and unemployment have a significant positive long-term impact on productivity. Rising wages and unemployment leads to the growth of productivity and labour costs and this is leading to a loss of a job. But it is important also to mention that other factors have an impact on productivity. It follows, that besides the impact of wage and employment impact on productivity it is necessary to talk also about the investment and capital influence on productivity. As productivity is growing also the country's outputs and public welfare is increasing. Accordingly, businesses can increase wages and dividends by maintaining the same price level and increasing the amount of production. Companies pay higher wages because (Trpeski \& Tashevska, 2009): wage affect efficiency and human health, improve the quality of the workforce, motivate employees to put more efforts and reduce the rotation of employees and it means that employees can work more productive, faster and longer in one workplace. It follows that productivity growth has a positive impact on economic development and wage growth and shareholders will receive higher returns from invested capital. If high wages follows from the increased productivity, then it helps to increase the profit of companies and encourage more efforts to work and to avoid redundancy. It confirms the idea that productivity, wage, employment, investment and capital are interrelated and affects competitiveness.

To sum up, the relation between wage, employment and productivity are widely analysed and at the same time a relevant issue. Based on the results of deep literature analysis, it is possible to formulate the research hypothesis - The employment variable has the weakest effect on the factors that influence productivity. Here is a few problem areas: there is selected a period of time, that does not reflect the actual situation or is selected inappropriate countries, so it is necessary to flexibly respond to the gaps that have emerged and to carry out a thorough analysis of the mentioned factors (wage, employment, productivity, capital and investment), which would reflect the real situation in the Baltic States.

\subsection{Theoretical aspects of wages}

This section defines the broader concept of wage, the structure of wages is characterized and the factors influencing wages and the main theories of wage determination are identified. 


\subsection{The analysis of wage concepts, objective and functions}

Wage is a widely assessed category which is explaining intangible motivational factors (better working conditions, honours, participation in courses of qualification growth) and defining the material value of wage (Hossain, Haque, \& Haque, 2015; Šilingienè, Stukaitè, \& Radvila, 2015; Bargain \& Peichl, 2016).

In economic terms, wage is treated as a financial form of financial reward or tangible benefit, which is calculated taking into account the expected working hours or as a macroeconomic indicator that shows the level of labour demand, the competitiveness of sectors and the ability of certain sectors of activity to pay the greater wage than others (Hossain et al., 2015; Šilingiene et al., 2015; Bargain \& Peichl, 2016). For every employee, the wage is the most important source of income, which ensures the employee's social prestige, affects their living standards, consumption and the country's economic situation.

Wage also is seen as one of the main factors that motivate to work productively, because wage tends to increase as workers become more skilled, thus helps to assess the image of the profession and one of the key factors that encourage the choice of the appropriate workplace. Wages should be adequate to the employee's professional knowledge, effort to work and their qualification and employee must have to improve his/her qualification continuously and acquire the necessary knowledge.

The main objective of wage is to restore the ability to work and work efficiently. The objective is also reflected in wage functions. Wages as an economic category perform five basic functions (Bukowska \& Łukasiewicz, 2017):

- restorative - close to the objective of wage, because it creates preconditions for meeting physical, mental and social needs and compensates the cost of living of employees;

- compensatory - occurs when worker work conditions are worse than accepted (night shifts, difficult conditions) and obtain a relatively higher wage;

- motivational - wage promotes employee satisfaction with the work done and increases their motivation to work efficiently, as well as improves the quality of the workforce and decreases the turnover of the employee;

- cumulative - occurs when wage ensure the accumulation of funds to meet future needs;

- social guarantees - ensures that more attention is paid to the qualification, work skills, personal qualities of employee and that is the base of the wage differentiation.

So, it can be said, that wage is a financial return to an employee for the proper use of his workforce and a motivational level to work more productively. The clearer way in which wages are set and employee have an appropriate qualification, skills and need the more motivated to work purposefully and productively employee is. Here wage is assessed as an economic category that affects both the individual employee status in the society and the economy of the country as a whole. In that way wage defines the financial evaluation of an employee's efforts, depending on the qualifications, skills and is an important macroeconomic rate which is linked to other economic categories (the main gross domestic product) in the macro level.

\subsection{Factors determining wage}

As has already been mentioned, the wage is money for the performance of a particular job and the monetary expression of a personal contribution to the organization activity. Wage is the most important factor in the company and country level because on the one hand money are the profit of the employees and on the other hand - the costs of the employers. The assessment of relevant work and its effects are stimulated through the formation of wage levels and composition, which is influenced by a set of factors. Wage and its structure are directly or indirectly influenced by many factors, which are divided into main internal and external factors. Some indicators (such as demographical) can be quantified, but some (health or employee skills) can only be evaluated qualitatively. Based on the scientific literature the internal and external factors determining wage are defined (Figure 2).

Figure 2 shows that factors determining wage are divided into internal and external. The group of internal factors consists of the factors of human capital (describing the personality, psychological condition, health and marital status), the characteristic of the employee (describing the persona s an employee - his/her skills, competence and professional qualification) and the characteristic of the employee and employer (describing both the enterprise and the job position and the employer's ability to pay the fixed wage) (Hossain et al., 2015; Litwin, 2015; Šilingienè et al., 2015; Bargain \& Peichl, 2016; Pytliková, Filipová, Balcar, \& Gottvald, 2016; Bhattarai, 2017; Phillips, Stauser, Ritter, Notaro, \& Jones, 2018). The level of wage is determined by the ,personal qualities of the employee, their education and qualification, which means that there are differences between a qualified and unskilled employee“.

It is difficult to replace the employees with high qualification and extensive work experience so the employers are forced to pay higher wages to keep these employees in their current workplace. The level of wages is also determined by external factors, which are divided into "legal/political, economic, social and technological" (Hossain et al., 2015; Leckcivilize, 2015; Litwin, 2015; Šilingienè et al., 2015; Pytliková et al., 2016), which are analysed at the sectoral level. External factors reflect the "ratio between supply and demand for skilled labour force". When labour supply exceeds labour demand employers may pay less, but as demand increases employers are forced to increase the wage 
due to the wage level in this region, the level of living in the country and the government's regulation and impact but in that way wage partly lost the motivator role.

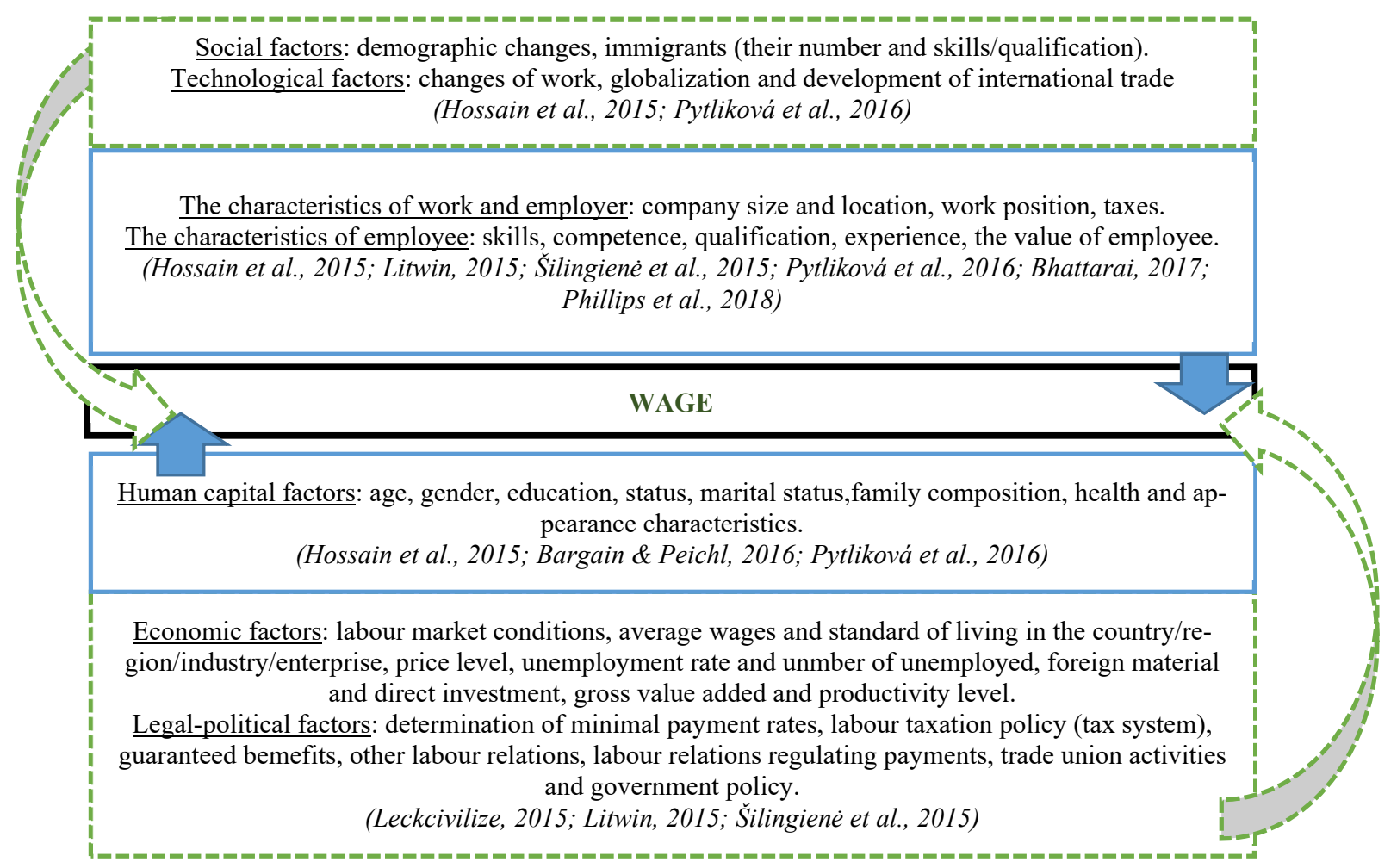

Figure 2. Factors influencing the wage level (source: compiled by the author based on scientific literature analysis)

Based on the analysis of the scientific literature can say that the group of economic factors (especially investment, gross domestic product and productivity) should be distinguished the most because the economic indicators are the base of the country's competitiveness. However social factor (demographic indicators) and technological (globalization, which is the base for changes in wage setting) should also be taken into account. These factors affect wages both internally and externally. When the influence of the mentioned factors is not properly managed, wage mismatches occur with the existing qualification, productivity and differentiation of wages. In order to minimize the negative impact, it is very important to evaluate the impact properly and to predict its purposefulness. This can be achieved by using demand and supply curves as the basis for wage-setting theories.

\subsection{Theories of wage determination}

Wage is a broad category that reflects the relationship between employee and employer and salary that is influenced by internal and external factors. In the works of many scientists special attention is paid to widespread wage theories (Table 2): classical, neo-classical, efficient wages, Keynes and neo-Keynes, marginal productivity wage, wage fund, subsistence wage, residual claimant and modern.

Summarizing the main theories of wage determination it can be said that the demand-supply balance and its dependence on macroeconomic factors (political, economic, social or technological factors) should be taken into account when determining efficient wages. Modern economists argue that the labour market activity is perfectly characterized by the neoclassical theory of a perfectly competitive market, which is seen as a combination of demand and supply curves (where demand growth and supply decrease leads to the wage growth and the growth of supply and demand decrease leads to the decrease of the wage), and the point of intersection of these curves reflects the level of efficient wages, which is the base for the growth of productivity.

Table 2. The main wage determination theories (source: compiled by the author based on scientific literature analysis)

\begin{tabular}{|l|l|l|l|}
\hline \multicolumn{1}{|c|}{ Theories } & \multicolumn{1}{c|}{ Supporters } & \multicolumn{1}{c|}{ Essence } & \multicolumn{1}{c|}{ Sources } \\
\hline $\begin{array}{l}\text { The classical theory } \\
\text { of wages }\end{array}$ & $\begin{array}{l}\text { A. Smith, D. Ricardo, } \\
\text { T. R. Malthus, K. Marx, } \\
\text { J. S. Mill, J. B. Say }\end{array}$ & $\begin{array}{l}\text { The labour cost and wages are determined by } \\
\text { the conditions of perfect competition and full } \\
\text { employment. }\end{array}$ & Kaya \& Tiğli, 2016 \\
\hline
\end{tabular}


End of Table 2

\begin{tabular}{|l|l|l|l|}
\hline \multicolumn{1}{|c|}{ Theories } & \multicolumn{1}{|c|}{ Supporters } & \multicolumn{1}{c|}{ Essence } & \multicolumn{1}{c|}{ Sources } \\
\hline $\begin{array}{l}\text { Neo-classical theory } \\
\text { of wages }\end{array}$ & $\begin{array}{l}\text { C. Menger, W. S. Jevons, } \\
\text { E. von Böhm-Bawerk, } \\
\text { L. Walras }\end{array}$ & $\begin{array}{l}\text { Increasing labour demand and supply create } \\
\text { wage minimization and employees are forced to } \\
\text { work for the lowest wage in the market. }\end{array}$ & $\begin{array}{l}\text { Golnau, 2012; } \\
\text { Greenwood, 2016 }\end{array}$ \\
\hline $\begin{array}{l}\text { Keynes and neo- } \\
\text { Keynes theory of } \\
\text { wages }\end{array}$ & J. M. Keynes & $\begin{array}{l}\text { Labour force and wage are rigid. Economic } \\
\text { equality is possible with incomplete employ- } \\
\text { ment. }\end{array}$ & Markowicz, 2015 \\
\hline $\begin{array}{l}\text { Efficient theory of } \\
\text { wages }\end{array}$ & H. Leibenstein, R. Solow & $\begin{array}{l}\text { In order to reduce the wage differentiation em- } \\
\text { ployers have to set such a wage that is within } \\
\text { the efficient wage curve and the workforce } \\
\text { elasticity should be equal to 1. }\end{array}$ & $\begin{array}{l}\text { Leibenstein, 1957; } \\
\text { Solow, 1979; } \\
\text { Golnau, 2012 }\end{array}$ \\
\hline $\begin{array}{l}\text { Marginal productiv- } \\
\text { ity theory of wages }\end{array}$ & J. R. Hick & $\begin{array}{l}\text { Under conditions of perfect competition, wages } \\
\text { are determined by measuring marginal revenue } \\
\text { productivity and average revenue productivity, } \\
\text { while productive workers receive higher wages. }\end{array}$ & $\begin{array}{l}\text { Biewen \& Weiser, } \\
2011\end{array}$ \\
\hline $\begin{array}{l}\text { Wage fund theory } \\
\text { of wages }\end{array}$ & A. Pigou & $\begin{array}{l}\text { The wage fund is directly related to the number } \\
\text { of employees, so when the fund falls, wages are } \\
\text { also getting smaller. }\end{array}$ & Pigou 1949 \\
\hline $\begin{array}{l}\text { Subsistence theory } \\
\text { of wages }\end{array}$ & D. Ricardo & $\begin{array}{l}\text { Wage must always be adequate for the mini- } \\
\text { mum standard of living. }\end{array}$ & Ricardo 1817 \\
\hline $\begin{array}{l}\text { Residual claimant } \\
\text { theory of wages }\end{array}$ & F. A. Walker & $\begin{array}{l}\text { Wage is the compensation received for a contri- } \\
\text { bution to a work process when the amount of } \\
\text { capital remains linked with the other factors. }\end{array}$ & Walker 1968 \\
\hline $\begin{array}{l}\text { The modern theory } \\
\text { of wages }\end{array}$ & G. Stigler & $\begin{array}{l}\text { Wage is the price of productive labour, which is } \\
\text { determined by the conditions of labour demand } \\
\text { and supply relations. }\end{array}$ & Stigler 1946 \\
\hline
\end{tabular}

\subsection{Theoretical aspects of employment}

When analyzing the relationship between employee and employer, it is necessary to define the concept of employment and its importance to the economy. In terms of social evaluation researcher (Schaefer, 2017) totally agree to the concept of full employment and adds that „employment is the relationship between the employee and employer to create a unified product or to provide the customer with the service they need“. It follows, that employment is ,,a purposefully developed relationship between employee and employer". It should be emphasized that in order to achieve the overall goal of creating a product or service, employees must be rewarded, because employment and employment relationships occur when ,a person is employed for a certain period of time and performs work for reward (money)“ (O'Brien, Spaventa \& De Corninck, 2016).

From a legal point of view, the employment relationship between the employee and the employer must be legalized by a contract and the employers and employees agree on the regulation of working time, the duration of the working week and other working conditions when signing such a contract (Srivastava, 2016). By employing a traditional form of employment, the employee is employed by signing a non-fixed-term employment contract and agreeing to work full-time (eight hours) and five days a week. In this way stable, long-term employment with hierarchical relationships is realized (Bąk-Grabowska \& Jagoda, 2016). The employer provides tasks that the employee has to implement and will be able to receive the agreed wage.

The technological changes which start at $1970 \mathrm{y}$. increasing international mobility of workers and capital in developed countries has required a transformation of employment conditions. Globalization and technological development, the growth of competitiveness and migration highlight the need to increase labour market flexibility. Constant changes in the labour market do the traditional forms of employment more flexible and occurs the transformation of traditional forms of employment (full-time employment: eight working hours, from Monday to Friday, one employer per employment contract) into flexible forms (which are affected by education, improvement in professional development and other factors) and the development of wage systems (Dobrowolska, 2016). This transformation also creates preconditions for atypical forms of employment.

New, atypical forms of employment are manifested in the flexibility of "working time (depending on working hours and needs), workplace (when the employee is not working), quantitative (a division of labour and optimization of employment) and functional flexibility (job matching)" (Bąk-Grabowska \& Jagoda, 2016). The demand for new goods and services requires innovation through the use of technical, technological, organizational and administrative 
solutions specific to the information economy, which defines the demand for innovative employment. The most widespread form of employment requires innovative types of staff who is skilled, proactive, and creative, working on internationally recognized standards, has management skills, is capable to adopt innovation in the broad perspective and are able to implement them. Less widespread forms of employment are temporary management and underwriting management of work under civil contracts (Schaefer, 2017).

Globalization and the rapid adoption of ICTs stimulate the development and change f forms of employment, which makes traditional forms of employment irrelevant and atypical forms of employment penetrate the market. According to researchers (Dachs \& Peters, 2014; Van Der Hoeven, 2014; Fang, Memili, Chrisman \& Penney, 2017; Schaefer, 2017) changes in employment are explained by changes in innovation, labour demand, wages and other important factors and employment is linked to economic growth as higher productivity in economic activity in the country has a positive impact on employment changes. Based on a review of scientific literature Figure 3 shows the system of main factors that affect employment.

\begin{tabular}{|c|c|c|c|c|c|c|}
\hline $\begin{array}{l}\text { Globalization, } \\
\text { innovations and } \\
\text { capital mobility }\end{array}$ & Inflation & $\begin{array}{l}\text { GDP and } \\
\text { the balance } \\
\text { of trading }\end{array}$ & $\begin{array}{c}\text { The dynamic of } \\
\text { population }\end{array}$ & $\begin{array}{l}\text { Economic growth } \\
\text { and productivity }\end{array}$ & $\begin{array}{l}\text { The poverty line, } \\
\text { the level of pri- } \\
\text { ces and wage }\end{array}$ & $\begin{array}{l}\text { Institutional ar- } \\
\text { rangements }\end{array}$ \\
\hline \multicolumn{7}{|c|}{$\begin{array}{c}\text { Macro level factors } \\
\text { (Dachs \& Peters, 2014; Van Der Hoeven, 2014; Schaefer, 2017) }\end{array}$} \\
\hline \multicolumn{7}{|c|}{ EMPLOYMENT } \\
\hline \multicolumn{7}{|c|}{$\begin{array}{c}\text { Micro level factors } \\
\text { (Dachs \& Peters, 2014: Fang et al., 2017) }\end{array}$} \\
\hline $\begin{array}{l}\text { The characte- } \\
\text { ristic of emp- } \\
\text { loyee }\end{array}$ & $\begin{array}{l}\text { Qualification } \\
\text { and skills of } \\
\text { the employee }\end{array}$ & $\begin{array}{l}\text { Activity } \\
\text { type }\end{array}$ & $\begin{array}{l}\text { Activity } \\
\text { branch }\end{array}$ & $\begin{array}{l}\text { Size of the orga- } \\
\text { nization }\end{array}$ & $\begin{array}{l}\text { The kind of la- } \\
\text { bour contract }\end{array}$ & $\begin{array}{c}\text { The amount of } \\
\text { wage }\end{array}$ \\
\hline
\end{tabular}

Figure 3. Factors influencing employment (source: compiled by the author based on scientific literature analysis)

Factors affecting employment are divided into smaller (micro-level) and larger (macro-level). Micro-level factors affecting employment and are related to the characteristics of employees and organization. Employment depends most of all on age and gender. The ageing of the workforce also has a major impact as the younger and stronger worker the more likely it is to have a stable and good job. Employment also depends on the qualifications and skills of the employees. From the company's perspective the employment rate is most dependent on the size of the organization, the sector and branch of the activity (Dachs \& Peters, 2014; Fang et al., 2017): the bigger organization and more perspective activity are, the higher is the demand of the employees. Also, one of the most important aspects of micro-level employment is the amount of offered wage. Higher wage creates the preconditions for the growth of labour supply and employment growth.

At the macro level employment is influenced by accelerating globalization, developing innovations and increasing capital mobility. Globalization is a precondition for openness to trade, better working methods and constant capital movement. The innovative transformation of employment is the result of the work of many competitive employees and depends on the form of legal cooperation, constructive trust between the social partners, a division of labour, peculiarities of old and new technologies. Employment also depends on the specialization of scientific engineering and technological skills, investment in human capital development and investment in new forms of (Schaefer, 2017). As the capital is mobile, the shareholders anticipate where to invest the available funds and where to build businesses (in which areas to increase employment).

Summarizing the main features of employment it was concluded that the development of employment depends on the existing situation in the external environment, especially the accelerating processes of globalization, the development of innovations and increasing capital mobility, therefore it can be said that besides the wage (as the main motivation of employees) and employment (as an expression of the relationship between the employee and the employer and the overall objective of monetary targeting), the country's competitiveness is also influenced by innovation and capital and is therefore used in further analysis in the areas of wages, employment, investment (especially investment in innovation) and capital data. 


\section{The results of the assessment of productivity and its determinants}

In order to achieve the ultimate objective - to evaluate the relationship between productivity and its determinants, it is expedient to carry out the analysis of the strength and purposefulness of the connection. This article provides a detailed analysis of productivity and its determinant to confirm or deny the hypothesis. Also, the research limitations are used: amount (due to the analysis of productivity and its determinants it is possible that not all factors that have an influence on productivity are included in the concept of research), time (the data of the 1995-2017 y.y. are analyzed) and the method (the most appropriate alternative for the analysis is the use of the Granger causality test).

\subsection{The methodology of the assessment of productivity and its determinants}

The assessment of productivity is an important part of economic research, which helps to define the smaller aspects of assessment in the overall assessment of strategic economic development decisions, taking into account common criteria. It is suggested to use different methods to evaluate productivity (Strauss \& Wohar, 2004; Karaalp-Orhan, 2017): global competitiveness index, total factor productivity, cointegration and Granger causality test and other. According to the analysis of scientific literature, the most reliable and widely used of investigating the directness and strength of the relationship between productivity and the factors determining it is the cointegration and Granger causality test.

Granger causality test is closely related to the vector autoregression (VAR) model (Götz, Hecq, \& Smeekes, 2016). C. Granger (1969) presented the concept of causality, which states that the existence of $X$ dependence on $Y$ and the knowledge of the values of $\mathrm{X}$ and $\mathrm{Y}$ can predict the trend of $\mathrm{Y}$. the Granger causality test for time series is based on the assumption that if $\mathrm{X}$ affects $\mathrm{Y}$, then $\mathrm{X}$ changes should occur before $\mathrm{Y}$ changes, but not the other way around. This means that the Granger causality test measures causality between the two variables $\mathrm{X}$ and $\mathrm{Y}$ and explains how many current $\mathrm{Y}$ values can be explained by changes in $\mathrm{X}$ values, while also assessing the effect delay (Hassaballa, 2014).

Engle and Granger (1987) argue that variables are cointegrated if they have a stochastic trend, so, here 5 variables are analysed (Eurostat, 2018): gross domestic product (Yt), employment (X1), wage (X2), capital (X3) and investment (X4). These factors are selected on the basis of theoretical assumptions that productivity depends on employment (the more workers will be employed, the faster work will be done), wage (as a motivational lever because the more wages will match the efforts made, the more motivated to work productively the employees will be), capital (technological opportunities and human capital development, which has a positive impact on the production process - shortening it but making it more productive and qualitative) and investment (additional opportunities for productive work).

Productivity is seen as a gross domestic product per employee, and it consists of asset productivity (fixed), asset (Technical supply), net value added. Determination of cointegration of variables in two times series $y_{t}$ and $x_{t}$ casethe the equation of regression (Vetlov, 2000):

$$
y_{t}=\sum_{i=1}^{k} \alpha_{i} y_{t-i}+\sum_{i=1}^{k} \beta_{i} x_{t-i}-u_{t},
$$

where $u_{t}-$ "white noise" remains.

From the condition, that $\beta \_\mathrm{i}=0(\mathrm{I}=1.2, \ldots,=\mathrm{k})$ is a statistically acceptable restriction it follows that $x_{t}$ is not the cause $y_{t}$. This means that the Granger causality test determines the influence of one variable past observations on the current value of another variable (Chu, Wu, \& Qiu, 2016). The results of the causality test are sensitive to external influences and times, so based on the causal relationship and causality analysis it is necessary to select the appropriate number of lags. The Granger test is based on a simple Wald test that allows you to test the significance of the number of delays for a second variable. With this approach to causality, it is possible to determine the number of delays in the equality of another variable autoregressive model and improve the prediction of another variable (Bilen, Yilanci, \& Eryüzlü, 2017). It is necessary to select the number of delays that meet the standard criteria of stationarity (shows the correlation, normal distribution, homoscedasticity) (Vetlov, 2000). For the Granger causality test, based on the VAR delays methodology, the optimal on-time delay was selected.

Applying the Granger causality test the Eqns (2) and (3) of the regression model are created.

$$
\begin{aligned}
& y_{t}=\alpha_{0}+\sum_{i=1}^{m} \alpha_{i} y_{t-i}+\sum_{i=1}^{m} \beta_{i} x_{t-i}+\varepsilon_{t} \\
& x_{t}=\alpha_{0}+\sum_{i=1}^{m} \alpha_{i} x_{t-i}+\sum_{i=1}^{m} \beta_{i} y_{t-i}+u_{t}
\end{aligned}
$$

where $\varepsilon_{t}$ ir $u_{t}$ - are non-correlated random errors (,white noise“). 
Testing is based on the hypothesis. The zero hypothesis states that $\mathrm{X}$ is not the cause of $\mathrm{Y}$ Granger causality (and variables are not cointegrated). In this way, double relationships between two variables in different regression equations are analysed and it is checked whether the values of one variable are sufficiently informative to predict the values of another variable (Hassaballa, 2014). The assessment of F statistics is used to verify the combined hypothesis (for each equation a zero hypothesis on the statistical significance of the coefficients is checked) (Hassaballa, 2014).

Panel data and time series are used to verify hypothesis in the VAR technique. One series of data is used to predict relationships with the second, and the essence of the model is that a zero hypothesis is almost always justified (Aslan, 2014). The essence of the causality analysis is to assess whether $Y$ affects $X$, or $X$ has an influence on $Y$ and whether $\mathrm{X}$ and $\mathrm{Y}$ are addictive or not. It should be noted that the influence of $\mathrm{X}$ and $\mathrm{Y}$ indicates the possibility of causality and the rejection of the zero hypothesis means that $\mathrm{X}$ is not the cause of $\mathrm{Y}$. A 5\% significance level is selected for testing hypothesis. If $p$ values remain higher than the selected significance level $(\alpha=0.05)$ it shows that $X$ values are the cause of Y Granger. In this case, the zero hypotheses that X is not the cause of Y Granger is rejected.

At this article, the following research limitations are applied. First is the amount of limitation and relates to the analysis of literature and a list of factors that determine productivity. In the analysis, it is possible that the concept does not include all the factors that directly affect productivity. Factors are distinguished based on the concepts presented in the analysis of available scientific literature, but the author of this article did not get to know the whole of the topics covered by worldwide publications and it is likely that the list of those factors may be added in the future. However, this fact does not diminish the significance of the study and only the inclusion of four factors (wages, employment, capital and investment) gives the study concerned an appropriate weight. The second limitation relates to the investigation period. The analysis covers the period 1995-2017 y. y. This period is chosen because the data for the main macroeconomic indicators are only available in national and international databases since $1995 \mathrm{y}$. and $2017 \mathrm{y}$. is chosen because it was the latest available data at the time of the survey. The third limitation is related to the selection of research methods. The analysis of the scientific literature revealed that the most appropriate alternative for the analysis is the use of the Granger causality and cointegration tests).

\subsection{The benefit of cointegration and Granger causality test calculation for the assessment of productivity and its determinants}

By applying the Granger causality test it is necessary to predict the direction and importance of the relationship between factors. The impact of the four factors (employment, wage, capital and investment) (which were distinguished on the base of literature review) on the productivity and the relationship of these factors in the Baltic states (Lithuania (LT), Latvia (LV) and Estonia (EE)) are analysed. Figure 4 shows the results of the Granger causality test, the impact of factors on productivity and the relationship between them.

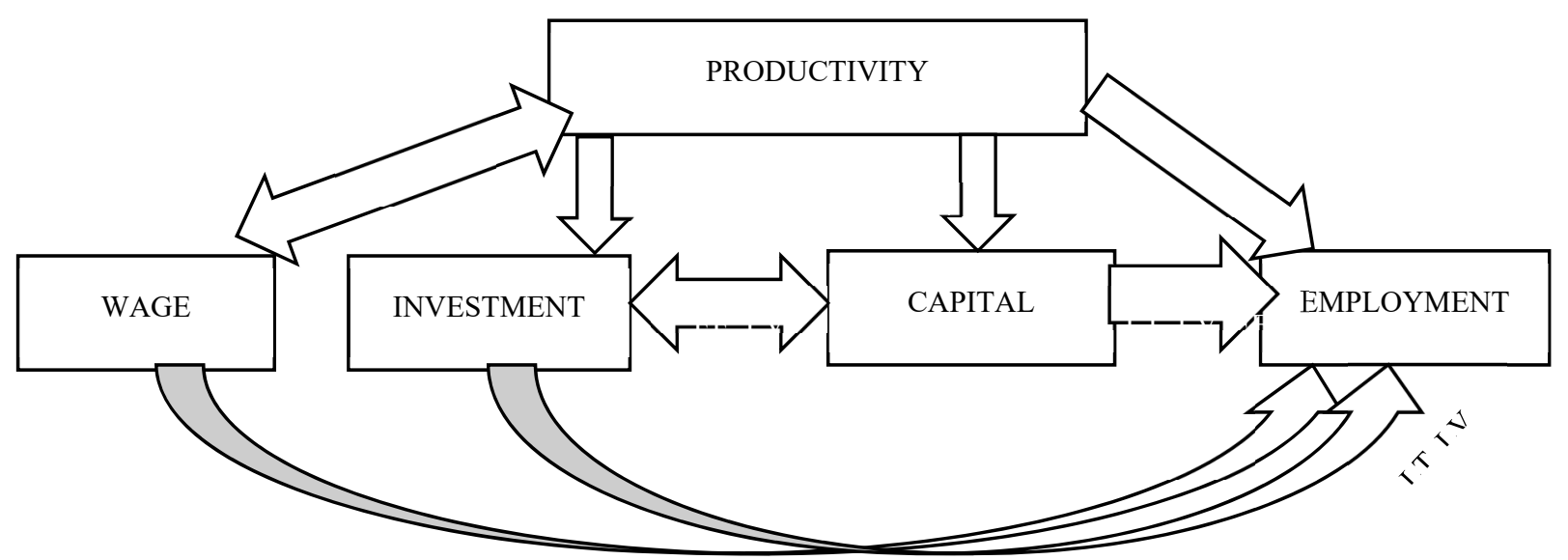

Figure 4. Granger causality test results (source: compiled by the author based on own calculations)

Based on the results, there is a close relation between wage, employment, investment, capital and productivity. Also, the countries, where H1 hypothesis (that the variables are the cause of Granger and are cointegrated) are true, are excluded. To sum up, it can be said, that there are close interrelations between the above-mentioned factors in the Baltic States, but wages (in the case of Estonia and Lithuania) have the strongest impact on productivity. There is also a strong relationship between investment and capital (in Estonia and Latvia) (the significance level is 0.05), because if investments are made in capital (or human capital) development, then these investments will have a positive impact on both productivity and the factors that determine it. Special attention should also be paid to the fact, that all activities have an impact on employment, which in turn has a small effect on any of these factors. This justifies the hypothesis of the analysis that employment is the weakest factor in the assessment of factors affecting productivity, which is least relevant to other factors after the Granger causality test and has no significant impact on productivity. Also, based on 
the results of the cointegration test, the hypothesis that the variables are cointegrated and the significance level of the data is 0.05 was accepted. Also, the hypothesis, that the impact of wages, employment, investment and capital on productivity is weakest in the context of employment is accepted.

\section{Conclusions}

Productivity is the expression of the efficiency of the use of production factors, which is characterized by the necessity of technological development and the improvement of human resources. If the human factor is motivated to work properly, adapting to constantly changing environmental conditions, through market monitoring and flexible forms of employment, productivity will increase and, accordingly, the competitiveness position of a particular country will improve.

From all factors that influence productivity, it is the most appropriate to distinguish the main four: wage, employment, investment and capital. Wage is a financial return to the employee for the proper use of his workforce and a motivational lever to work more productively. The way the wage setting is clearer and is in line with the employee's qualifications, skills and needs, the more motivated the employee is to work purposefully and productively. The development of employment depends on the existing situation in the external environment, but particularly on the accelerating processes of globalization, development of innovation and increasing capital mobility, so it can be said that besides wages (as the main motivation lever of employee) and employment (as an expression of the relationship between employee and employer and main objective of country) factors, the investments and capital are also influenced the productivity.

Assessing the link between the wages, employment, investment, capital and productivity, can be formulated a hypothesis - the employment variable has the weakest effect on the productivity and there are three limitations: volume, period and methods. The causality of the factors and the factors relationship at the $5 \%$ significance level can be also checked using Granger causality test.

Analysing productivity and its determination using the cointegration and Granger causality test it can be concluded that there is a close relation between wages, employment, investment, capital and productivity. The hypothesis that the employment variable has the weakest impact on productivity, while investment and wages had the greatest impact on productivity was accepted with the significance level 0.05 . It can be argued that there is a close relationship between the above factors in the Baltic States, but wages (in Estonia and Lithuania) have the strongest impact on productivity. There is also a strong relationship between investment and capital (in Estonia and Latvia), because if the investment is made in capital development or human capital development, then these investments will have a positive impact on both productivity and the factors that determine it.

\section{References}

Annunziata, M., \& Bourgeois, H. (2018). The future of work: how G20 countries can leverage digital-industrial innovations into stronger high-quality jobs growth. Economics: The Open-Access, Open-Assessment E-Journal, 12(2018-42), 1-23. https://doi.org/10.5018/economics-ejournal.ja.2018-42

Aslan, A. (2014). Tourism development and economic growth in the Mediterranean countries: evidence from panel Granger causality tests. Current Issues in Tourism, 17(4), 363-372. https://doi.org/10.1080/13683500.2013.768607

Baležentis, T. (2013). Partial factor productivity in Lithuanian family farms: the multiplier data development analysis approach. Management Theory and Studies for Rural Business and Infrastructure Development, 35(1), 25-33.

Bargain, O., \& Peichl, A. (2016). Own-wage labour supply elasticities: variation across time and estimation methods. IZA Journal of Labour Economics, 5(10), 1-31. https://doi.org/10.1186/s40172-016-0050-z

Bąk-Grabowska, D., \& Jagoda, A. (2016). Non-standard forms of employment and working time flexibility - the categories of cooccurrence?. Journal of International Studies, 9(1), 209-219. https://doi.org/10.14254/2071-8330.2016/9-1/17

Bhattarai, K. (2017). Determinants of wages and labour supply in the UK. Chinese Business Review, 16(3), 126-140. https://doi.org/10.17265/1537-1506/2017.03.002

Biewen, M., \& Weiser, C. (2011). A new approach to testing marginal productivity theory. IZA Discussion Paper Series, 6113, 152.

Bilen, M., Yilanci, V., \& Eryüzlü, H. (2017). Tourism development and economic growth: a panel Granger causality analysis in the frequency domain. Current Issues in Tourism, 20(1), 27-32. https://doi.org/10.1080/13683500.2015.1073231

Bukowska, U., \& Łukasiewicz, G. (2017). Wynagrodzenia jako czynnik stabilizujący zatrudnienie w organizacji. Organizacja $i$ kierowanie, 3(177), 79-94.

Chu, X., Wu, Ch., \& Qiu, J. (2016). A nonlinear Granger causality test between stock returns and investor sentiment for the Chinese stock market: a wavelet-based approach. Applied Economics, 48(21), 1915-1924. https://doi.org/10.1080/00036846.2015.1109048

Dachs, B., \&; Peters, B. (2014). Innovation, employment growth, and foreign ownership of firms: a European perspective. Research Policy, 43, 214-232. https://doi.org/10.1016/j.respol.2013.08.001

Dobrowolska, M. (2016). Importance of flexibility of employment in the professional education of persons endangered by social exclusion. European Journal of Economics and Business Studies, 4(1), 8-13. https://doi.org/10.26417/ejes.v4i1.p8-13 
Engle, R. F., \& Granger, C. W. J. (1987). Co-integration and error correction: representation, estimation, and testing. Econometrica, 55(2), 251-276. https://doi.org/10.2307/1913236

Eurostat. (2018). Labour force survey in the EU, candidate and EFTA countries. Luxembourg: Publications Office of the European Union. $76 \mathrm{p}$.

Fang, H., Memili, E., Chrisman, J. J., \& Penney, Ch. (2017). Industry and information asymmetry: the case of the employment of non-family managers in small and medium-sized family firms. Journal of Small Business Management: Researching Entrepreneurship in Family Firms, 55(4), 632-648. https://doi.org/10.1111/jsbm.12267

Flachenecker, F. (2018). The causal impact of material productivity on macroeconomic competitiveness in the European Union. Environmental Economics and Policy Studies, 20(1), 17-46. https://doi.org/10.1007/s10018-016-0180-3

Golnau, W. (2012). Wybrane modele w teorii płacy efektywnej. Zarzadzanie i Finanse, 10(4), 283-296.

Götz, T. B., Hecq, A., \& Smeekes, S. (2016). Testing for Granger causality in large mixed-frequency VARs. Journal of Econometrics, 193, 418-432. https://doi.org/10.1016/j.jeconom.2016.04.015

Granger, C. W. J. (1969). Investigating causal relations by econometric models and cross-spectral methods. Econometrica, 37, 424438. https://doi.org/10.2307/1912791

Greenwood, D. T. (2016). Institutionalist theories of the wage bargain: beyond demand and supply. Journal of Economic Issues, 50(2), 406-414. https://doi.org/10.1080/00213624.2016.1176493

Grześ, A. (2017). Outsourcing w ksztaltowaniu zatrudnienia oraz kosztów i produktywności pracy w przedsiębiorstwach. Białystok; Uniwersytet w Białymstoku.

Hassaballa, H. (2014). Testing for Granger causality between energy use and foreign direct investment inflows in developing countries. Renewable and Sustainable Energy Reviews, 31, 417-426. https://doi.org/10.1016/j.rser.2013.12.011

Hossain, K. A., Haque, Sh. M., \& Haque, A. K. E. (2015). An analysis of the determinants of wage and salary differentials in Bangladesh. South Asia Economic Journal, 16(2), 295-308. https://doi.org/10.1177/1391561415598467

Karaalp-Orhan, H. S. (2017). Labour productivity, real wages and unemployment: an application of bounds test approach for Turkey. Journal of Economic and Social Development, 4(2), 11-22.

Kaya, M. V., \& Tığlı, A. (2016). Wage theories and an applicable wage model proposal for Turkey’s labour markets. Çankırı Karatekin University Journal of The Faculty of Economics and Administrative Sciences, 6(1), 501-523.

Leckcivilize, A. (2015). Does the minimum wage reduce wage inequality? Evidence from Thailand. IZA Journal of Labor \& Development, 4(21), 1-23. https://doi.org/10.1186/s40175-015-0041-7

Leibenstein, H. (1957). The theory of underemployment in backward economies. Journal of Political Economy, 65(2), 91-103. https://www.jstor.org/stable/1827366; https://doi.org/10.1086/257894

Litwin, B. S. (2015). Determining the effect of the minimum wage on income inequality. Student Publications, 300, 1-22.

Markowicz, I. (2015). Statystyczna analiza przestrzennego zróżnicowania bezrobocia w Polsce. Studia Ekonomiczne, 223, $247-256$.

O'Brien, C., Spaventa, E., \& De Corninck, J. (2016). Comparative report 2015 - the concept of worker under article 45 TFEU and certain non-standard forms of employment. Project Report. European Commission, Brussels. 228 p.

Ottaviano, G. I. P., Peri, G., \& Wright, G. C. (2018). Immigration, trade and productivity in services: evidence from U. K. firms. Journal of International Economics, 112, 88-108. https://doi.org/10.1016/j.jinteco.2018.02.007

Peluffo, A. (2015). Foreign direct investment, productivity, demand for skilled labour and wage inequality: an analysis of Uruguay. The World Economy, 962-983. https://doi.org/10.1111/twec.12180

Phillips, B. N., Stauser, D. R., Ritter, E. S., Notaro, S. J., \& Jones, W. D. (2018). The influence of social capital and social role on starting wage for people with and without disabilities. Rehabilitation Counseling Bulletin, 62(1), 43-52. https://doi.org/10.1177/0034355217749297

Pigou, A. C. (1949). Mill and the wages fund. The Economic Journal, 59(234), 171-180. https://doi.org/10.2307/2226682

Pytliková, M., Filipová, L., Balcar, J., \& Gottvald, J. (2016). Reinvestigating the determinants of gender wage gap: evidence from the survey. In Proceedings of the 14th International Scientific Conference Economic Policy in the European Union Member Countries: September 14-16, 2016, Petrovice u Karviné, Czech Republic. Part 1. Karviná: Slezská Univerzita v Opavě, Obchodně podnikatelská fakulta v Karviné, 2016, 1-13.

Ricardo, D. (1817). On the principles of political economy and taxation. London: John Murray. 333 p.

Sawicki, L. (2015). Kształtowanie wydajności pracy w Polsce na początku XXI wieku. Przedsiębiorstwo i region, 7, 93-104. https://doi.org/10.15584/pir.2015.7.10

Schaefer, M. (2017). Non-standard employment in the EU and Ukraine. Сучасні механізми забезпечення сочіально-економічноі безпеки на макро- та макрорівнях: матеріали I Міжнародної науково-практичної конференції. Дніпро: Університет митної справи та фінансів, 2017, 116-119.

Solow, R. M. (1979). Alternative approaches to macroeconomic theory: a partial view. The Canadian Journal of Economics, 12(3), 339-354. https://doi.org/10.2307/134726

Srivastava, R. (2016). Structural change and non-standard forms of employment in India. Conditions of work and employment series, $68,1-64$.

Stigler, G. (1946). The economics of minimum wage legislation. American Economic Review, 36(3), 358-365. https://www.jstor.org/stable/1801842

Strauss, J., \& Wohar, M. (2004). The linkage between prices, wages and labour productivity: a panel study of manufacturing industries. Southern Economic Journal, 70, 920-941. https://doi.org/10.2307/4135280 
Šilingienè, V., Stukaitè, D., \& Radvila, G. (2015). Darbo užmokestị lemiantys veiksniai: Lietuvos žemès ūkio sektoriaus atvejis. Management Theory and Studies for Rural Business and Infrastructure Development, 37(2), 297-309. https://doi.org/10.15544/mts.2015.27

Trpeski, P., \& Tashevska, B. (2009). Labor productivity and wages in the Republic of Macedonia. The Young Economists Journal, l(13), 103-112.

Ugur, M., Churchill, S. A., \& Solomon, E. (2018). Technological innovation and employment in derived labour demand models: a hierarchical meta-regression analysis. Journal of Economic Surveys, 32(1), 50-82. https://doi.org/10.1111/joes.12187

Van Der Hoeven, R. (2014). Full employment target: what lessons for a post-2015 development agenda?. Journal of Human Development and Capabilities: A Multi-Disciplinary Journal for People-Centered Development, 15(2-3), 161-175. https://doi.org/10.1080/19452829.2014.883370

Vetlov, I. (2000). Lietuvos infliacijos inercijos analizè. Pinigu studijos, 3, 5-16.

Walker, F. A. (1968). The wage question. New York: Kelly Publisher. 262 p.

Yusof, S. A. (2008). The long-run and dynamic behaviours of wages, productivity and employment in Malaysia. Journal of Economic Studies, 35(3), 249-262. https://doi.org/10.1108/01443580810887805 